\title{
CITIZEN SATISFACTION WITH ONLINE PASSPORT SERVICE INNOVATION IN INDONESIA WITHIN AN ELECTRONIC GOVERNANCE PERSPECTIVE
}

\author{
Saleh, Choirul \\ Public Administration Program, Faculty of Administrative Sciences, Brawijaya University, \\ Malang, Indonesia \\ Corresponding Author: choirulsaleh@ub.ac.id
}

\begin{abstract}
This research investigated, measured, analyzed and explained citizen satisfaction with the online passport application service innovation introduced by the Immigration Office of East Java Immigration Area. In addition, this research also evaluated which types of innovation (technology, access, process, and product and payment method) had the strongest and weakest influence on citizen satisfaction. This research was conducted using a quantitative method, allowing researchers to systematically measure, analyze and explain the effect of the online passport application service on citizen satisfaction. The population for this research included all online passport applicants determined by the quota of each office in the study (189,000, applicants per year). A total of 250 samples were selected based on Slovin's formula. This research was conducted over 6 months in Immigration Office Class 1 of Surabaya, Immigration Office Class 1 of Malang and Immigration Office Class 2 of Blitar. Research data were analyzed using product moment analysis in order to investigate the partial and multiple regression of the independent variable (technology, access, process, product and payment method) $X$ toward the dependent variable (citizen satisfaction) $Y$. The results of statistical tests showed that of the innovations studied (technology, access, process, product and payment method) had both partial and multiple contributions and a significant effect on citizen satisfaction. The originality of this research lies on the fact that both national and international-scale research on the contribution of five innovations (technology, access, process, product and payment method) toward citizen satisfaction when applying online for a passport had not been conducted before.
\end{abstract}

Keywords: Public Service Innovation, Citizen Satisfaction, Partial and Multiple Regression

Cite this Article: Saleh, Choirul, Citizen Satisfaction with Online Passport Service Innovation in Indonesia within an Electronic Governance Perspective, International Journal of Management (IJM), 10 (6), 2019, pp. 61-75.

$\mathrm{http}: / /$ iaeme.com/Home/issue/IJM?Volume $=10 \&$ Issue $=6$ 


\section{INTRODUCTION}

Seen from the formal and juridical point of view, the implementation of public service by Indonesian Government Institutions is specifically ruled by Act Number 25 of 2009. This regulation indicates that the government of Indonesia pays strong attention to public servicerelated programs, as such programs are essential to meet the needs of the citizen. In addition, effective implementation of public services by the government not only strengthens the democratic process, but also enhances the quality of human rights fulfillment, public trust, and social welfare. It also helps to decrease the poverty rate, improve national defense and security, provides ease of service, legal protection and fulfills other needs of the citizen (Hutahaen, et al: 2018; Denhardt \& Denhardt: 2007).

Act Number 25 of 2009 explains in detail that the scope of public service in Indonesia includes many kinds of services, which can be grouped in three broad categories: 1) services to meet the needs of the public good, 2) services to meet the needs of public services, and 3) administrative services. The objectives of this study were focused on an investigation of innovations in delivering administrative services resulting from citizens' demands for online passport issuance by the Immigration Office. The main function of the Immigration Office is to issue travel permit documents, leave permits and return permits in the form of passports, hereinafter referred to as the Surat Perjalanan Republik Indonesia (SPRI) or Travel Letter of the Republic of Indonesia. To provide fast, accurate, precise, easy, affordable and friendly administrative services for passport issuance, the Directorate General of Immigration of the Ministry of Law and Human Rights Republic of Indonesia (KEMENKUMHAM RI), as a higher organization than the Immigration Office, launched a new innovation, namely a WhatsApp Gateway Service (WAGS) on May 17, 2017. This innovation is in addition to the existing innovation programs. There are five types of innovation offered in the WAGS that match government to citizen relationship ( $\mathrm{G}$ to $\mathrm{C}$ ), which consists of; technological innovation, access innovation, process innovation, product innovation and payment method innovation. This WAGS innovation was trialed in 18 Immigration Offices from August 7, 2017 and has received broadly positive responses from users. The application has been simultaneously used in all regions, especially in Immigration Offices of Class 1 and Special Class 1 . According to the Electronic Governance (E-Gov) perspective, the application of the WAGS system is one of the E-Gov schemes currently being applied by the Directorate General of Immigration aimed at creating innovative public services, which can be accessed by citizens more easily, quickly, appropriately, and cheaply. Also, it can be accessed anytime and anywhere without being constrained by distance and time (Siddiquee; 2018), (Pradana, Fanida, \& Niswah; 2017 However, for developing countries like Indonesia, the application of a quality E-Gov with high satisfaction for citizens is not a simple matter that needs to be studied seriously and systematically so that the benefits can truly be enjoyed by citizens who need it.

The Head of Public Relations and General Affairs of the Directorate General of Immigration, (Agung Sampurno) said that the application of the WAGS system allowed citizens to apply for passport issuance without having to queue in the office, as they are able to simply register via the passport queue application. This WAGS system helps citizens to access and obtain a queue schedule when applying for passports online. The WAGS system also reduces bureaucratic procedures and uses time more efficiently. Before the WAGS system was introduced, passport applicants had to queue in the office, which took effort and energy as they had to come to the office at least three times on different days. The process of passport issuance from the registration to the final procedure took approximately 1 to 2 weeks. After the WAGS system was implemented, applicants only had to visit the office twice and it took only three days to complete the passport issuance process. According to the Head of Public Relations and General Affairs of the Directorate General of Immigration, one of the main objectives of this 
innovation was to find and provide solutions to solve various problems in the organization. This is consistent with Mulgan and Albury (2003), who explained that any innovation carried out by public sector organizations is generally intended to provide alternatives to solve various problems. Furthermore, public service innovation also increases public trust and citizen satisfaction (Bouckaert \& Van de Walle; 2003).

However, the application of the WAGS system up to the beginning 2019 did not solve all the problems that occur with online passport issuance. The $\mathrm{G}$ to $\mathrm{C}$ relationship has been successfully enhanced but other problems have emerged, resulting in citizen dissatisfaction toward the service. One of the most prominent problems was related to the difficulty in accessing or logging in to the service to get a queue schedule. This was caused by numerous issues, including the lack of comprehensible information provided, which meant that applicants had to access the application many times. Some applicants even failed to access the service to get a queue schedule without obtaining any information regarding the causes of failure experienced by the applicant. When they successfully accessed their schedule, they still experienced relatively long waiting periods of 1 to 3 weeks from the moment they managed to access the system through the WAGS application in receiving information and calls to ask the applicant comes to the Immigration Office to get the initial service for the passport issuance application by bringing the required personal documents. The waiting period is not regarded as efficient by users, especially by those who have urgent affairs abroad. Unfortunately, thepassport issued by the Directorate General of Immigration KEMENKUMHAM-RI still receives little interest from citizens for a variety of reasons.

This study was conducted to measure, evaluate and analyze the level of citizen satisfaction with the administrative service innovations provided by the Immigration Office and to find solutions and make suitable recommendations for the improvement of the WAGS system application increase citizen satisfaction. Hence, on one side, the results of this study can be used to provide recommendations to improve and increase the quality of the innovation of online epassport issuance that must be done by the Immigration office to serve more quickly, accurately, properly, easily, cheaply and simply, and nicely for citizens as a user. On the other hands, it can also be used to provide recommendations so that the e-passports will become a more desirable, useful, and safer new service product because it is an important document for the owner which contains three main functions; the Country Signing Certification Authority (CSCA) Certificate and the Document Signer Certificate (DSC) and Document Security Object (DSO).

\section{LITERATURE REVIEW}

\subsection{Public Sector Organization Roles as Public Service Providers}

The Ministry of Administrative and Bureaucratic Reform of the Ministry of National Development Planning KEMENPANRB-RI or (RI-2018) affirmed that the main purpose of organizing public services for Indonesia is to fulfill citizens' expectations, demands, needs and desires. Therefore, the state of public services must be regarded as a stimulant for the government to provide better public services to all citizens. It is absolutely essential that this is taken seriously as Indonesia is a democratic country and public services are the responsibility of the government. Hence, it would be challenging for public sector organizations in Indonesia to enhance their capacity in carrying out their roles as reliable public service providers in order to fulfill the expectations, demands, needs and desires of the citizens to improve the public welfare, public trust and public satisfaction toward the government.

Imaduddin (2016) has explained that the quality of goods provided by a country for the citizen and the quality of public services are citizens' rights and are obligations for a country to fulfill. In the past, some citizens were often neglected with regards to the fulfillment of public services by public service providers, and similar problems may still occur. Public sector 
organizations as providers, and public officials and civil servants, should accept their responsibilities to deliver public services and no longer assume that the public services they provide for the citizens are merely administered to simply fulfill their obligations as daily duties. According to Doherty \& Horn (2005) and Withon (2007), to make the government as the provider truly realize the quality, responsible and satisfying process of public service implementation, it must be based on the four Es principles: economy, efficiency, effective and ethically.

The implementation of the four E's principles is challenging as the focus of public service provision today, and in the future, is on achieving world-class government by 2025 . Whereas, the implementation of these principles should give more emphasis on improving the quality of services in order to truly satisfy citizens. Imaduddin (2016) also added that the development of public service quality, compared to the demands, needs and expectations of the community, was like a series of arithmetical measures. Thus, without proper breakthroughs and innovative actions, citizens' satisfaction with the performance of public services in Indonesia will decline.

Consequently, it is necessary to bring innovation to the public services in Indonesia. The government needs to implement innovative programs and continue to find reliable methods to provide fast, precise, accurate, easy, affordable, friendly and excellent public services for citizens. These goals can be achieved if the innovative programs are supported by effective and transformative public sector leadership. According to Bass and Avolio (1994), transformative leadership has four basic dimensions called the four Is: idealized influence, inspirational motivation, intellectual stimulation and individualized consideration. An additional dimension (initiative) completes the other four dimensions as this dimension allows innovative actions to be conducted quickly, which is the core of an effective leadership. The implementation of these five dimensions is expected to lead to new breakthroughs and leaps that are positive, proactive and progressive for the betterment of the country.

\subsection{Public Service Innovation and Electronic Government}

E-Gov as mentioned by Bertot, Esteves, Janowsky; (2016), which Sakowitz (2003) and Seifert (2003) also referred to as E Gov, belongs to the fifth stage of the public service digitalization process - the connected phase (UN Government survey; 2018). In this phase, the government, together with other related institutions, starts to use advanced technology to provide 24-hour non-stop public services for the citizens (Siefert: 2003, Sakowicz:2003). These actions are consistent with the concepts of innovation in E-Gov. Moreover Drucker (2001) that E-gov. is the utilization of Information and communication technologies (ICT) intensively and systematically used to facilitate the work process of government institutions and public administration in providing quality public services. In other words, public service innovations in E-Gov perspective is an introduction to new elements that can be adopted into public service practices implemented by public service providers. Those various elements, according to Osborne \& Kerry (2005), can be in the form of new knowledge, new organizations, new management patterns, new technologies or new processual skills and new products whose presence is discontinuity with the past. However, Osborne \& Brown (2011) emphasizes that the context of Public service innovation, both normative, technical and practical, must have positive tendencies. Innovation can also be regarded as a process of discovering new ideas and new values, as well as progressive and positive practical services, to bring betterment and higher community satisfaction (Wood et al: 1998, Morris: 2006, O'Sullivan:2008). Government carries out public service innovations to:

- Fulfill citizens' expectations, demands and needs.

- Improve cost efficiency, especially in dealing with tight budgeting.

- Improve the quality of goods and service delivery by becoming faster and more accurate. 
- Use advancements in ICT to achieve fast, precise, easy, affordable and high-quality public services for the citizens.

- Expand the positive effects of improved service quality to all citizens.

The public service innovation program needs to take into consideration the forms of innovation that actually enhance citizen satisfaction. According to Wood et al (1988), product innovation and process innovation are two common forms of innovation in both business and public sector organizations. While Damanpour and Gopalakrishnan in Lekhy (2007) identified innovations that were especially relevant to public services-product innovations, service innovations, and organizational (procedural or process) innovations.

Responding to differences in theorists' views on the types of innovations, practitioners, especially those who work in public sector organizations and whose duty is to carry out public service innovation actions, believe that it is unnecessary to contradict those views because it is more important to choose and think of the types of innovation that best suit individual needs. Practitioners may eclectically take one view and combine it with other views. Public sector service practitioners need to realize that public service innovations can be carried out if new approaches are used to create new value, methods and practices that accurately target the essential needs of individuals and citizens. According to an Act of Permenpan and Reform of Bureaucracy No. 30 of 2014 concerning Guidelines for Public Service Innovation and Innovation Needs of Institutions of State Administration, innovation is seen as a creative process of knowledge creation to make different or new discoveries and/or modifications of the existing ones. Meanwhile Schermernhorn (1993) said that innovative actions can be taken through four stages, which include an idea creation, initial experimentation, feasibility determination and final application phases. From a macro perspective, innovation is the art, science and practice that can change difficult, expensive, imprecise, old and cumbersome processes into easy, affordable, fast, precise, accurate and better ones to enhance citizen satisfaction. Furthermore, innovation is a structured and collaborative process that involves all parts of the organization, at all levels and for all types of work, and it involves outside parties finding new ways of problem-solving and capturing opportunities that they want to achieve.

\subsection{Public Service Satisfaction}

Citizen satisfaction with public services provided by the government is a direct response by the citizens. This response may be positive or negative, depending on the quality of the service received and whether the service meets the person's expectations. Satapathi et al (2014) noted that citizen dissatisfaction with public services should be avoided. However, better quality of service can only be achieved through successful innovations in public services implemented by the government. Boukkaert (1995) declared that if the service quality is improved to match citizens' expectations, then citizen satisfaction will increase and vice versa. Whereas, Kotler (2005) stated that satisfaction is a feeling of pleasure or disappointment that comes from making comparisons between the impression of the goods or services actually received, and the expectations of those goods and services. This suggests that satisfaction appears from the impression of the provider's performance and the expectations of citizens. If the provider's performance is below expectations, citizens will become dissatisfied. Conversely, if the performance of the provider meets or exceeds citizens' expectations, citizen satisfaction will be higher, leading to stronger public trust.

Measuring customer satisfaction is important for business organizations as it can improve their competitiveness in maintaining and expanding their share of the market, which leads to optimal profit. The level of customer satisfaction can also be used by business organizations to obtain information about consumers' preferences, needs and expectations, which can then be considered when making decisions related to market competition (Cengiz, 2010; Hussain, 
2015). In commerce, all consumers believe that the quality of goods and services are the first and foremost consideration before they decide to buy goods and or services. These considerations determine whether or not they will purchase the goods and or services offered (Khan, Batool \& Hussain; 2015). Thus, business organizations are eager to make new innovations to make their consumers satisfied with the goods and or services they offer to create customer enthusiasm and loyalty.

Unlike business organizations, public sector organizations do not generally allow citizens to choose the goods and services they prefer, due to the monopoly rights of public sector organizations as public service providers. Therefore, even though citizens find the services dissatisfying, they cannot choose other providers as they have no alternative options. This condition leads to lower trust and loyalty of citizens towards public sector organizations because the government fails to provide quality public services and they do not properly implement service innovations. Hence, citizen satisfaction with public services has to be measured as an attempt to gain higher public trust and public loyalty (Van De Walle; 2016). Some parameters can be used to measure citizen satisfaction with services provided by public sector organizations. These include security, utility and social norm principles (Martínez, Short; 2015). Furthermore, according to the Minister of Menpan No. 63 of 2003 there are ten principles of excellent service consisting of: a) simple, b) clear, c) definite, d) accurate, e) safe, f) responsible, g) complete, h) easy, i) disciplined, polite and friendly, and j) comfortable.

Public sector organizations must always strive to improve the quality of the services they offer in order to increase citizen satisfaction. Also, the quality of services will not be improved if public sector organizations do not make innovations. In this context, Wahyudi (2016) said that public service innovations that are properly implemented will give added value to the services provided. This added value then increases citizen satisfaction. Therefore, leaders and decision makers in public sector organizations must be creative in seeking opportunities to make innovations that give added value and that eventually lead to higher satisfaction. In the other words, the implementation of public service innovations can be achieved through new approaches, new ways of working and new technologies that can increase the positive values that meet the demands, needs and expectations of citizens.

A number of studies support this current research, including national-scale studies conducted by: Imaduddin (2016), Wahyudi (2016), and Saleh et al (2013) and internationalscale studies by Siefert (2003), Sakowicz (2003), Boukkaert (1995), Kotler (2005), Cengiz (2010), Hussain (2015), Khan, Batool \& Hussain (2015). After consideration of the previous work in this area, we formulated six research hypotheses:

$\mathrm{H}_{1}$. There is a significant correlation between technological innovation and citizen satisfaction.

$\mathrm{H}_{2}$. There is a significant correlation between access innovation and citizen satisfaction.

$\mathrm{H}_{3}$. There is a significant correlation between process innovation and citizen satisfaction

$\mathrm{H}_{4}$. There is a significant correlation between product innovation and citizen satisfaction.

$\mathrm{H}_{5}$. There is a significant correlation between payment method innovation and citizen satisfaction.

$\mathrm{H}_{6}$. There is a significant simultaneous correlation between technological, access, process, product and payment method innovations and citizen satisfaction.

\section{METHODOLOGY}

This study employed inferential statistical analysis in the form of partial regression analysis and multiple regression analysis (Mangkoedihardjo, 2010; Mangkoedihardjo and April, 2012). In addition, Pearson product-moment analysis was also carried out. The results of partial 
regression analysis show the contribution or influence of each independent variable on the dependent variable. While, the results of multiple regression analysis indicate the simultaneous contribution or influence of all independent variables: technological innovation (X1), access innovation (X2), process innovation (X3), product innovation (X4) and payment method innovation (X5) on the dependent variable citizen satisfaction (Y). Likert Scales were used to measure the variables and the distribution of the respondents' answers (see Tables1 and 2).

Table 1 The Criteria for Responses Toward the Service

\begin{tabular}{|c|l|c|}
\hline No & \multicolumn{1}{|c|}{ Criteria } & Score \\
\hline 1 & Highly not innovative & 1 \\
\hline 2 & Not Innovative & 2 \\
\hline 3 & Less Innovative & 3 \\
\hline 4 & Innovative & 4 \\
\hline 5 & Highly innovative & 5 \\
\hline
\end{tabular}

Table 2 The Criteria for Responses toward the Service Received.

\begin{tabular}{|c|l|c|}
\hline No & \multicolumn{1}{|c|}{ Criteria } & Score \\
\hline 1 & Highly Dissatisfied (STP) & 1 \\
\hline 2 & Dissatisfied (TP) & 2 \\
\hline 3 & Less Satisfied (KP) & 3 \\
\hline 4 & Satisfied (P) & 4 \\
\hline 5 & Highly Satisfied (SP) & 5 \\
\hline
\end{tabular}

The population for this research was online passport applicants in three Immigration Offices: the Special Class 1 Immigration Office of Surabaya, the Class 1 Immigration Office of Malang and the Class 2 Immigration Office of Blitar. These offices were within the work area of the Regional Office of the Ministry of Law and Human Rights in East Java. Surabaya is the capital city of East Java and has an area of $47,922 \mathrm{~km}^{2}$, and a population of $42,030,633$, based on the 2017 population census. East Java has the largest area of the six provinces in Java and has the second largest population in Indonesia, after West Java, making it methodologically representative as a population area.

Purposive and proportional simple random sampling methods were used to select the target respondents, including applicants who had actually submitted their passport applications online. The age attributions of the selected respondents were: adolescence, productive age and old age. The number of samples is shown in Table 3 .

Table 3 The Number of Online Passport Applicants Served by Immigration Offices Per Year

\begin{tabular}{|c|c|c|c|c|c|c|}
\hline No. & Immigration Office & $\begin{array}{l}\text { Quota } \\
\text { Per Day }\end{array}$ & $\begin{array}{l}\text { Quota } \\
\text { Per Year }\end{array}$ & $\begin{array}{c}\text { Number of } \\
\text { Samples/ } \\
\text { Respondents }\end{array}$ & $\begin{array}{l}\text { Age } \\
\text { Group }\end{array}$ & $\begin{array}{c}\% \\
\text { Population }\end{array}$ \\
\hline 1. & $\begin{array}{l}\text { Class } 1 \text { Special } \\
\text { Immigration Office } \\
\text { of Surabaya }\end{array}$ & 300 & 90,000 & $120 *)$ & \multirow{4}{*}{$\begin{array}{l}\text { Adolescent } \\
\text { Productive } \\
\text { Elders }\end{array}$} & 20 \\
\hline 2 & $\begin{array}{l}\text { Class } 1 \text { Immigration } \\
\text { Office of Malang }\end{array}$ & 250 & 75,000 & $100 *)$ & & 50 \\
\hline 3 & $\begin{array}{l}\text { Class } 2 \text { Immigration } \\
\text { Office of Blitar }\end{array}$ & 80 & 24,000 & $30 *)$ & & 30 \\
\hline \multicolumn{2}{|c|}{ Total Population } & 630 & 189,000 & $250 *)$ & & 100 \\
\hline
\end{tabular}

Source: Primary Data Processed

*) Rounded Up 


\section{RESULTS OF ANALYSIS}

\subsection{The Distribution Model of Frequency and Percentage}

The percentage distribution and frequency distribution of the responses to the five types of innovation in the online passport application service are shown in Table 4.

Table 4 Frequency Distribution and Percentage Distribution Related to the Implementation of Online Passport Application the Innovation Variables of Online Passport

\begin{tabular}{|c|c|c|c|c|c|c|c|c|c|c|c|c|c|c|c|}
\hline \multirow[b]{2}{*}{ No } & \multirow[b]{2}{*}{ Var. } & \multicolumn{2}{|c|}{ STI (1) } & \multicolumn{2}{|c|}{ TI (2) } & \multicolumn{2}{|c|}{ KI (3) } & \multicolumn{2}{|c|}{ I (4) } & \multicolumn{2}{|c|}{ SI (5) } & \multirow{2}{*}{$\begin{array}{l}\text { Total f } \\
\text { Score }\end{array}$} & \multicolumn{2}{|c|}{ Sum } & \multirow[t]{2}{*}{ Average } \\
\hline & & f & $\%$ & f & $\%$ & f & $\%$ & f & $\%$ & f & $\%$ & & Sum & $\%$ & \\
\hline 01 & $\mathrm{X}_{1}$ & 0 & 0 & 20 & 8 & 32 & 13 & 93 & 37 & 105 & 42 & 1.033 & 250 & 100 & 4.13 \\
\hline 02 & $X_{2}$ & 10 & 4 & 22 & 9 & 55 & 22 & 83 & 33 & 80 & 32 & 0.951 & 250 & 100 & 3.80 \\
\hline 03 & $X_{3}$ & 0 & 0 & 14 & 6 & 26 & 10 & 94 & 38 & 116 & 46 & 1.062 & 250 & 100 & 4.25 \\
\hline 04 & $\mathrm{X}_{4}$ & 15 & 6 & 25 & 10 & 50 & 20 & 85 & 34 & 75 & 30 & 0.930 & 250 & 100 & 3.72 \\
\hline 05 & $\mathrm{X}_{5}$ & 0 & 0 & 5 & 2 & 13 & 5 & 112 & 45 & 120 & 48 & 1.097 & 250 & 100 & 4.39 \\
\hline Tot & & & & & & & & & & & & & & & 4.06 \\
\hline
\end{tabular}

Source: Primary Data Processed

It can be seen from Table 7 that frequency distribution and percentage distribution of online passport applicants stated that of the five innovations, technological innovation $\left(\mathrm{X}_{1}\right)$, process innovation $\left(\mathrm{X}_{3}\right)$ and payment method innovation $\left(\mathrm{X}_{5}\right)$ were considered good, because each variable had an average value $>4$. Access innovation $\left(\mathrm{X}_{2}\right)$ and product innovation $\left(\mathrm{X}_{4}\right)$ were considered fair because the average values of these variables were 3.80 and 3.72, respectively. In contrast, the average value for all innovations combined was $4.06>4$ and was considered good. While this result was pleasing there is still room for improvement.

Other than that, data on the percentage distribution shown in table 4 above reveals that the general response of citizens to the quality of innovation in online passport issuance services at the first level (highly innovative) only ranges from $32 \%$ to $48 \%$, while the second range is only in the range of $33 \%$ to $45 \%$. The percentage of a citizen who is less innovative about the quality innovation of online passport issuance ranges from only $5 \%$ to $22 \%$. Meanwhile, the number of the citizen who states the innovation quality of online passport issuance is still low or at the fourth level (not innovative) of between $5 \%$ and $25 \%$, and those say very low or at the fifth level (highly not innovative) between $10 \%$ and $15 \%$. Specifically, the data shows that the frequency distribution and the percentage of citizen responses to the lowest quality of public service innovation are in product innovation (Var. $\mathrm{X}_{4}$ ) with the distribution percentage of $30 \%$ and access innovation (Var. $\mathrm{X}_{2}$ ) with a percentage distribution of $32 \%$. This implies that those two innovations are the most dissatisfaction type, so they must get more attention than others. The level of citizen satisfaction with the online passport application process is shown in Table 5 .

Table 5 Frequency and Percentage Distribution of Citizen Satisfaction with the Online Passport Application Service (Y)

\begin{tabular}{|c|c|c|c|c|c|c|c|c|c|c|c|c|c|c|c|}
\hline \multirow[b]{2}{*}{ No } & \multirow[b]{2}{*}{ Var. } & \multicolumn{2}{|c|}{ STP (1) } & \multicolumn{2}{|c|}{ TP (2) } & \multicolumn{2}{|c|}{ CP (3) } & \multicolumn{2}{|c|}{$P(4)$} & \multicolumn{2}{|c|}{ SP (5) } & \multirow{2}{*}{$\begin{array}{c}\text { Total } \\
\text { f } \\
\text { Score }\end{array}$} & \multicolumn{2}{|c|}{ Sum } & \multirow[t]{2}{*}{ Average } \\
\hline & & $\mathrm{f}$ & $\%$ & F & $\%$ & $\mathrm{f}$ & $\%$ & $f$ & $\%$ & $\mathrm{f}$ & $\%$ & & Sum & $\%$ & \\
\hline 1 & $\mathrm{Y}$ & 2 & 0.8 & 20 & 8 & 30 & 12 & 93 & 37 & 105 & 42 & 1.029 & 250 & 100 & 4.11 \\
\hline
\end{tabular}

Source: Primary Data Processed

It can be seen from Table 5 that the average value for satisfaction was $4.11>4$ which means that most applicants were satisfied with the online passport service. Again, while this result is pleasing there is still some room for improvement. More than that, table 5 also informs about 
the distribution percentage value of citizen satisfaction towards the innovation of online passport issuance that is still relatively low. The percentage value of the first level (highly satisfied) is only $42 \%$, the second level (satisfied) is $37 \%$, the third level (less satisfied) is $12 \%$, the fourth level (dissatisfied) is $8 \%$, and the fifth level (highly dissatisfied) is $0.8 \%$. Figure 3 below clarifies the percentage value of citizen satisfaction on the innovation of passport issuance.

\subsection{Analysis: Partial Linear Regression Model}

The strength of relationship between each independent variable $\left(\mathrm{X}_{1}\right)-\left(\mathrm{X}_{5}\right)$ and citizen satisfaction (Y) was analyzed using a partial/t-test. This test was performed to determine whether each independent variable had a partial relationship and a significant effect on the dependent variable. If $t_{\text {count }}>t_{\text {table }}$ or $-t_{\text {count }}<-t_{\text {table, }}$, the relationship was considered significant and $\mathrm{H} 1$ was accepted. The results of the $t$ test are presented in Table 6.

Table 6 The Results of partial / t-test

\begin{tabular}{|c|c|c|c|}
\hline $\begin{array}{c}\text { Independent } \\
\text { Variable }\end{array}$ & $\mathbf{t}_{\text {test }}$ & Sig. & \multirow{2}{*}{ Note } \\
\hline (Constant) & 0.481 & 0.631 & \\
\hline $\mathrm{X}_{1}$ & 2.388 & 0.019 & Significant \\
\hline $\mathrm{X}_{2}$ & 2.922 & 0.004 & Significant \\
\hline $\mathrm{X}_{3}$ & 2.019 & 0.046 & Significant \\
\hline $\mathrm{X}_{4}$ & 2.245 & 0.027 & Significant \\
\hline $\mathrm{X}_{5}$ & 2.599 & 0.011 & Significant \\
\hline $\mathrm{t}_{\text {table }}$ & \multicolumn{2}{|c|}{1.986} & \\
\hline
\end{tabular}

The results of the test were explained as follows:

- For technological innovation $\left(\mathrm{X}_{1}\right)$ and the dependent variable $(\mathrm{Y}), \mathrm{t}_{\text {count }}=2.388>\mathrm{t}_{\text {table }}=1.986$ $(\alpha=0.05)$. This indicated that the relationship of variable $\left(\mathrm{X}_{1}\right)$ to citizen satisfaction $(\mathrm{Y})$ was significant, and $\mathrm{H} 1$ was accepted. In the other words, the level of citizen satisfaction (Y) was significantly influenced by independent variable $\left(\mathrm{X}_{1}\right)$ at a significance of $0.019<=\alpha 0.05$.

- For access innovation $\left(\mathrm{X}_{2}\right)$ and the dependent variable $(\mathrm{Y}), \mathrm{t}_{\text {count }}=2.922>\mathrm{t}_{\text {table }}=1.986(\alpha=$ $0.05)$ meaning that the relationship between access innovation $\left(\mathrm{X}_{2}\right)$ and citizen satisfaction $(\mathrm{Y})$ was significant, and $\mathrm{H} 1$ was accepted. Therefore, it was clear that citizen satisfaction (Y) was significantly influenced by the independent variable $\left(\mathrm{X}_{2}\right)$ with a significance of $0.004<=\alpha 0.05$.

- For process innovation $\left(\mathrm{X}_{3}\right)$ and the dependent variable $(\mathrm{Y}), \mathrm{t}_{\text {count }}=2.019>\mathrm{t}$ table $=1.986(\alpha=$ $0.05)$ meaning that the relationship between the variable $\left(\mathrm{X}_{3}\right)$ and citizen satisfaction $(\mathrm{Y})$ was significant and $\mathrm{H} 1$ was accepted. Therefore, it was concluded that the level of citizen satisfaction $(\mathrm{Y})$ was significantly influenced by variable $\left(\mathrm{X}_{3}\right)$ with a significance of $0.046<=\alpha 0.05$

- For product innovation $\left(\mathrm{X}_{4}\right)$ and the dependent variable $(\mathrm{Y}), \mathrm{t}_{\text {count }}=2.245>\mathrm{t}$ table $=1.986(\alpha=$ $0.05)$. Therefore, the relationship between $\left(\mathrm{X}_{4}\right)$ and citizen satisfaction $(\mathrm{Y})$ was significant and $\mathrm{H} 1$ was accepted. It was concluded that the level of citizen satisfaction $(\mathrm{Y})$ was significantly influenced by the independent variable $\left(\mathrm{X}_{4}\right)$ with a significance of $0.027<=\alpha 0.05$.

- For payment method innovation $\left(\mathrm{X}_{5}\right)$ and the dependent variable $(\mathrm{Y}), \mathrm{t}$ count $=2.599>\mathrm{t}$ table $=$ $1.986(\alpha=0.05)$ meaning that the relationship between variable $\left(\mathrm{X}_{5}\right)$ and citizen satisfaction $(\mathrm{Y})$ was significant and $\mathrm{H} 1$ was accepted. It was concluded that the level of citizen satisfaction (Y) was significantly influenced by the independent variable $\left(\mathrm{X}_{5}\right)$ with a significance of $0.011<=\alpha$ 0.05 .

The results of the partial correlation test showed that each independent variable $\left(\mathrm{X}_{1}\right)-\left(\mathrm{X}_{5}\right)$ had a significant influence on the satisfaction of the citizens (Y), who were the users of the services provided by immigration offices. 
Citizen Satisfaction with Online Passport Service Innovation in Indonesia within an Electronic Governance Perspective

\subsection{Analysis: Multiple Linear Regression Model}

Regression analysis, using the multiple linear regression formula below, was used to measure the strength of the relationship between independent variables $\left(\mathrm{X}_{1}\right)-\left(\mathrm{X}_{5}\right)$ and the dependent variable (Y). The results of the linear equations regression analysis are shown in Table 7.

Table 7 Linear equations of Regression Analysis Results

\begin{tabular}{|c|c|c|c|c|c|}
\hline $\begin{array}{c}\text { Dependent } \\
\text { Variable }\end{array}$ & \multicolumn{2}{|c|}{$\begin{array}{c}\text { Unstandardized } \\
\text { Coefficients }\end{array}$} & $\begin{array}{c}\text { Standardized } \\
\text { Coefficient }\end{array}$ & \multirow{2}{*}{ T } & \multirow{2}{*}{ Sig. } \\
\cline { 2 - 4 } & $\mathrm{B}$ & Std. Error & Beta & & \\
\hline (Constant) & 1.882 & 3.907 & & 0.482 & 0.632 \\
\hline $\mathrm{X}_{1}$ & 0.743 & 0.312 & 0.195 & 2.388 & 0.019 \\
\hline $\mathrm{X}_{2}$ & 0.885 & 0.304 & 0.225 & 2.922 & 0.005 \\
\hline $\mathrm{X}_{3}$ & 0.653 & 0.324 & 0.171 & 2.019 & 0.047 \\
\hline $\mathrm{X}_{4}$ & 0.762 & 0.340 & 0.209 & 2.245 & 0.028 \\
\hline $\mathrm{X}_{5}$ & 0.851 & 0.328 & 0.209 & 2.599 & 0.012 \\
\hline
\end{tabular}

The results of the linear equations regression analysis showed that all independent variables $\left(\mathrm{X}_{1}\right)-\left(\mathrm{X}_{5}\right)$ had a positive and significant relationship with the dependent variable $(\mathrm{Y})$ - citizen satisfaction -for the services provided by the three immigration offices (see Table10).

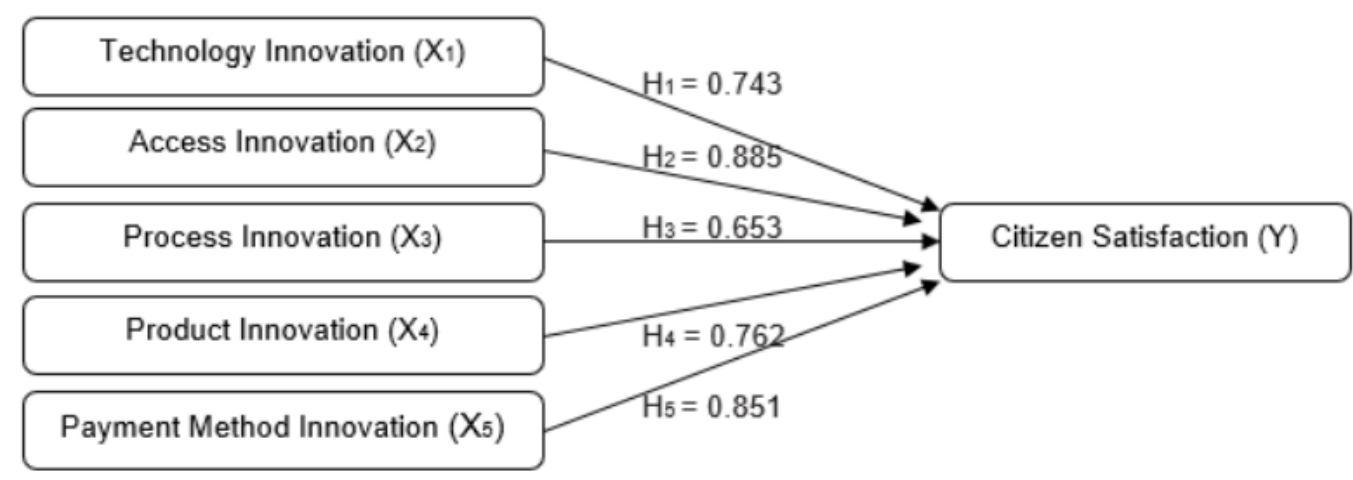

Figure 4 The pattern of multiple regression between variables $\left(X_{1}\right)-\left(X_{5}\right)$ and dependent variable $Y$

Starting from the results of the test, it can be interpreted that;

- Regression coefficients of variable $X_{1}$ are 0.743 ; if the technological innovation $\left(X_{1}\right)$ is increased by 1 unit, the citizen satisfaction will increase by 0.742 unit, with assumption variables $\mathrm{X}_{2}, \mathrm{X}_{3}, \mathrm{X}_{4}$, and $\mathrm{X}_{5}$ are constant.

- Regression coefficients of variable $X_{2}$ are 0.885 ; if the Acces Innovation $\left(X_{2}\right)$ is increased by 1 unit, the citizen satisfaction will increase by 0.885 unit, with assumption variables $\mathrm{X}_{1}, \mathrm{X}_{3}, \mathrm{X}_{4}$, and $\mathrm{X}_{5}$ are constant.

- Regression coefficients of variable $X_{3}$ are 0.653 ; if the Process Innovation $\left(X_{3}\right)$ is increased by 1 unit, the citizen satisfaction will increase by 0.653 unit, with assumption variables $X_{1}, X_{2}, X_{4}$, and $\mathrm{X}_{5}$ are constant.

- Regression coefficients of variable $\mathrm{X}_{4}$ are 0.762 ; if the Product Innovation $\left(\mathrm{X}_{2}\right)$ is increased by 1 unit, the citizen satisfaction will increase by 0.851 unit, with assumption variables $X_{1}, X_{2}, X_{3}$, and $\mathrm{X}_{5}$ are constant.

- Regression coefficients of variable $\mathrm{X}_{5}$ are 0.851 ; if the Payment Method Innovation $\left(\mathrm{X}_{4}\right)$ is increased by 1 unit, the citizen satisfaction will increase by 0.851 unit, with assumption variables $\mathrm{X}_{1}, \mathrm{X}_{3}, \mathrm{X}_{4}$, and $\mathrm{X}_{5}$ are constant.

Table 8 presents the results of correlational coefficient of determination calculations. It can be seen from Table 8 that the $\mathrm{R}^{2}$ value (coefficient of determination) was 0.627 , implying that $62.7 \%$ of citizen satisfaction was simultaneously influenced by the five independent variables, 
while $37,3 \%$ influenced by another variable but the magnitude of the $R$ value $(0.792)$ which was between $0.6-0.8$ indicated that the five independent variables share positive and strong influences toward citizen satisfaction as the dependent variable (Y).

Table 8 Correlational Coefficient of Determination

\begin{tabular}{|c|c|c|}
\hline $\mathbf{R}$ & $\mathbf{R}^{\mathbf{2}}$ & ${\text { Adjusted } \mathbf{R}^{\mathbf{2}}}$ \\
\hline 0.792 & 0.627 & 0.607 \\
\hline
\end{tabular}

Table 9 F Test/ Simultaneous Test

\begin{tabular}{|l|c|c|c|c|c|c|}
\hline \multicolumn{1}{|c|}{ Model } & $\begin{array}{c}\text { Sum of } \\
\text { Squares }\end{array}$ & Df & $\begin{array}{c}\text { Mean } \\
\text { Square }\end{array}$ & F count & F $_{\text {table }}$ & Sig. \\
\hline Regression & 2612.369 & 5 & 522.474 & 31.755 & 2.311 & 0.000 \\
\hline Residual & 1546.671 & 94 & 16.454 & & & \\
\hline Total & 4159.040 & 99 & & & & \\
\hline
\end{tabular}

Table 9 shows that the $\mathrm{F}$ count was 31.755 , while $\mathrm{F}$ table was $2.311(\alpha=0.05$; db regression $=$ $5: \mathrm{db}$ residual $=94)$. Since $F$ count $>F_{\text {table }}$ and the significance was $0.000<\alpha=0.05$, the regression analysis model was regarded as significant. Therefore, $\mathrm{H} 0$ was rejected and $\mathrm{H} 1$ accepted. Thus, the dependent variable (Y) was simultaneously influenced by all the independent variables: technological innovation $\left(\mathrm{X}_{1}\right)$, access innovation $\left(\mathrm{X}_{2}\right)$, process innovation $\left(\mathrm{X}_{3}\right)$, product innovation $\left(\mathrm{X}_{4}\right)$, and payment method innovation $\left(\mathrm{X}_{5}\right)$

\section{DISCUSSION}

The online passport application service is an effort to digitalize public service innovation (Bertot, Esteves, Janowsky; 2016) in order to improve the quality of administrative services, to meet the needs of the citizen and to improve citizen satisfaction. The statistical analysis of the data from online passport applicants showed that the independent variables shared both partial and simultaneous relationships in the forms of strong and significant influences on the dependent variable. This implied that the level of citizen satisfaction was influenced by the quality of service innovation carried out by Immigration Offices as public service providers. The results of the partial regression test showed that technological innovation significantly increased citizen satisfaction. This finding is consistent with the work of Parasuraman, Berry, and Zeithaml (1990), who found that the reliability of physical facilities (hard technology) was influential toward improvement in the quality of public services, and which later improved citizen satisfaction.

The partial regression test for access innovation also found a significant relationship and influence on citizen satisfaction. This implied that access innovations related to online passport application were of benefit to the citizens. The results for innovation of access showed that Immigration Offices have been able to provide easier, simpler and faster services for the citizen because citizens stating that this is innovative and very innovative form is only $33 \%$ and $32 \%$, respectively (see table 7 and figure 2). The reasons are when they access/log in the initial registration to get a service schedule, they still often have difficulties without getting an answer from the WAGS system provided by the Immigration Office. This indicates that the $\mathrm{G}$ to $\mathrm{C}$ relationship provided by WAGS system that is citizen engage in two-way traffic interaction in nature is still not optimal (Sakowitz; 203), (Siefert; 2003), especially that is the transact in nature (UN E-Governance Survey, 2008) because when the citizen has successfully registered to get the initial service, they even cannot choose the service schedule because by the Immigration Office.

The results for process innovation also showed that this variable had a significant influence on citizen satisfaction. The implementation of this innovation improved the precision and accuracy of the administrative process, eliminating the occurrence of procedural errors. Even 
though this innovation might be less appealing for public sector organizations, this innovation plays a great role in public service delivery as it applies more systematic procedures, methods and new ways in providing public services and goods for citizens. Moreover, the main focus of process innovation for public sector organizations is actually to improve the public service quality and public service delivery.

The results for product innovation, in the form of the e-passport, also showed significant influences on citizen satisfaction. This finding is supported by Agung (2018) who found that the e-passport application is also beneficial for Indonesia by producing better quality passport issuance, as determined by ICAO Standard. Personal data provided in the e-passport are also more accurate and secure. Because the percentage value of the innovative and highly innovative system only reaches $34 \%$ and $30 \%$, so this kind of innovation still needs to get serious attention to be repaired in the future. This is because they are unfamiliar with the e-passport and consider that it does not have better advantages and benefits compared to the conventional ones. Also, the reproduction cost is nearly three times of the conventional passport so that it has low competitiveness and is out of citizen's favor. Actually, the Immigration Office can issue epassports which, according to citizens, have higher competitiveness than the previous products, both in terms of benefits, safety, comfort, etc., so that even though the reproduction costs are more expensive than the conventional passport, it is still out of favor.

Citizen satisfaction was also found to be significantly influenced by the innovation in payment method. This innovation makes the payment process easy and very flexible. Hence, citizens as the ones who need these services, feel well-served by this innovation.

The results of multiple regression test also showed that each independent variable technological innovation $\left(\mathrm{X}_{1}\right)$, access innovation $\left(\mathrm{X}_{2}\right)$, process innovation $\left(\mathrm{X}_{3}\right)$, product innovation $\left(\mathrm{X}_{4}\right)$, and payment method innovation $\left(\mathrm{X}_{5}\right)$ - had a simultaneous influence on citizen satisfaction $(\mathrm{Y})$, but the strength of the influence $\left(\mathrm{R}^{2}\right)$ was only 0.607 (see Table 11). This implied that the strength of the simultaneous influence of all independent variables on the dependent variable was only $60.7 \%$, while the other $39.3 \%$ was influenced by other variables which were not considered in this research. On the other hand, these results allow us to recommend that Immigration Offices improve the quality of their innovations in the future, in order to enhance the influence of these innovations on citizen satisfaction.

Based on the results of this study, public service innovations have been found to have a positive and significant effect on citizen satisfaction. The findings of this research also support the results of prior research conducted by Mulgan and Albury (2003), Bouckaert \& Van de Walle (2003), Hutahaen et al (2018), Denhardt \& Denhardt (2007), Imaduddin (2016), Saleh et al (2013), Bertot, Esteves\& Janowsky (2016), Sakowitz (2003), Seifert (2003), Nigro \& Cisaro (2014), Andi (2016), Satapathi et al (2014), Cengiz (2010), Nigro \& Cisaro (2014), Khan (2015), Martinez, Short \& Ortiz (2015), Wahyudi (2016), Bekkers \& Tummers (2018), (Pradana, Fanida, \&Niswah; 2017). The researchers have revealed that public service innovations that can simplify and speed up the service process and produce appropriate and accurate service products will have an impact on the high level of citizen satisfaction with services provided by public sector organizations that act as providers.

\section{CONCLUSIONS AND IMPLICATIONS}

The results of the partial regression and multiple regression analysis conducted in this research showed that all service innovations implemented by Class 1 Special Immigration Office of Surabaya, Class 1 Immigration Office of Malang and Class 2 Immigration Office of Blitar had strong and significant influences on citizen satisfaction. This indicated that the innovation in public service delivery practices for granting permits for online passport applications positively affected citizen satisfaction. This provides solid evidence that the expertise of government 
organizations in selecting and implementing public service innovations greatly influences the satisfaction of their citizens.

The theoretical implications that can be extracted from the results of this research relate to the need for innovative actions that must be taken by the government, especially innovation in administrative services through E-Gov, internet government (I-Gov) and digital government (D-Gov) approaches which not only relies on technological sophistication but also considers the easily composable, affordability and awareness for its users. This research also proposes practical recommendations for all public sector organizations, as public services providers, to always prioritize citizen satisfaction by implementing more applicable innovative actions in performing their jobs.

It is important that Immigration Offices carefully review the quality of the innovations that they implement because this research shows that the actual influence made by these innovations is only $60.7 \%$ on the level of citizen satisfaction of citizens who have received services provided by the Immigration Office. Therefore, Immigration Offices should continue improving and adjusting their services which are simpler and easier to reach to meet the expectations and needs of citizens. This should lead to these innovations having a stronger influence on citizen satisfaction the future.

\section{REFERENCES}

[1] Bass, B.M., and Avolio, B.J, "The implication of transaction and transformational leadership for individual, team, and organizational development", Research in Organizational Change and Development, 1994, Vol. 4, pp. 231-272.

[2] Bekkers, V., \& Tummers, L., "Innovation In The Public Sector: Towards an Open And Collaborative Approach", International Review of Administrative Science,2018, Vol 84 (2) 2019-213

[3] Bertot,C. John, Esteves, Elsa \& Janowsky Thomasz; 2016, 'Digital Public Service Innovation: A Frame Work Proposal",ICEGOV2016, , Montevideo, Uruguay, March 1-3, 2016

[4] Bouckaert, G, "Remodeling Quality and Quantity in a Management Context", in A. Halachmi and Geert Bouckaert (eds) Public Productivity Through Quality and Strategic Management. Amsterdam: IOS Press, 1995

[5] Bouckaert, Geert \& Van de Walle, Steven., "Comparing Measures of Citizen Trust and User Satisfaction as Indicators of Good Governance": Difficulties of Linking Trust and Satisfaction Indicators, International Review of Administrative Sciences 2003; 69; 329,

[6] Cengiz, E.,"Measuring customer satisfaction: Must or Not?",Journal of naval science and engineering ,2010, 6,(2), 76-88.

[7] Doherty, Tony, L., \& Terry Horne, Managing Public Services Implementing Change, This Edition Published in The Taylor and Francis E-Library, , USA and Canada, Routledge Publisher, 2005

[8] Drucker P., F.,Electronic Governance in Context, Electronic Governance and Electronic Democracy: Living40 SYSTEMICS, CYBERNETICS AND INFORMATICS and Working in the Connected World: CommonwealthCentre for Electronic Governance, VOLUME 6 - NUMBER 6,2001

[9] Hutahaen, F. J, Gani, A. Y. A, Saleh, C. \& Sarwono, "The factors affecting the implementation of OpenFreedom information policy and public service performance: A case study at Jakarta Capital City Government", International Journal of Law and management,2018, Vol 60 Issue 2 Pp 505-516. 
Citizen Satisfaction with Online Passport Service Innovation in Indonesia within an Electronic Governance Perspective

[10] Imanuddin, Muhammad,"Inovasi Pelayanan Publik: Percepatan Peningkatan Kualitas Pelayanan Publik", diakses tabggal 21 Pebruari 2019 pada https://rsambkt.sumbarprov.go.id/berita-261https://rsam-bkt.sumbarprov.go.id/, 2016

[11] Khan. B.M, Batool, I., and Hussain. S, "Customer Satisfaction In Public Sector, A Case Study of Pakistan Housing Authority", Pakistan Journal of Social Sciences (PJSS) Vol. 35, No. 2 (2015), pp. 1037-1050.

[12] Lekhy, Rohit, "Public Service Innovation”, A Research Report for The Work Foundation's Knowledge Economy Programme, The Work Foundation Manchester, 2007

[13] Mangkoedihardjo, S, A new approach for the Surabaya sewerage and sanitation development programme 2020. Advances in Natural and Applied Sciences, 2010, 4 (3): 233-235.

[14] Mangkoedihardjo, S. and April, SAL, Compost on Evapotranspiration Bed Planted With Yellow Flag for Treatment of Wastewater Containing Anionic Surfactant. Journal of Applied Sciences Research, 2012, 8(3): 1630-1633.

[15] Martínez, L, Short, J \&Ortíz, “Citizen satisfaction with public goods and government services in the global urban south: A case study of Cali, Colombia", Habitat International Journal, Vol 49, 2015, 84-89

[16] Morris, Langdon, Permanent Innovation The Definitive Guide to the Principles, Strategies, and Methods of Successful Innovators, Download Edition, Ahkoff Center for The University of Pennsylvania, 2006

[17] Mulgan, G. and Albury, D, "Innovation in the Public Sector, Strategy Unit, Cabinet Office", 2003

[18] Nigro, Hector, O. \& Cisaro Elizabeth G, "Prediction of Citizen Satisfaction With Local Government Based on Perceptions of Physical Disorder", Journal of Place Management and Development Vol. 7 No. 2, 2014 pp. 153-175

[19] Osborne, Stephen P., and Louise Brown. Innovation, Public Policy andPublic Services: The Word that would be King? Public Administration 89(4), 2011, pp 1335-1350

[20] Osborne, Stephen, P., \& Brown, Kerry, A, Managing Change and Innovation in Public Service Organizations, First published by Routledge2 Park Square, Milton Park, Abingdon, Oxon OX14 4RN, 2005

[21] O'Sullivan, D, Applying Innovation: Sage Publishing, Thousand Oaks, California, 2008

[22] Pradana, G., W., Fanida, E., W., \& and Niswah, F., Intranet and village community: optimization of publicservice based on electronic government at the local level, The 2nd International Joint Conference on Science and Technology (IJCST) 2017 IOP PublishingIOP Conf. Series: Journal of Physics: Conf. Series 953(2018) 012160 doi :10.1088/1742-6596/953/1/012160

[23] Purnomo, Agung, S.,Citizen-Oriented Service Delivery And Innovation: A Case Study of Passport Office In Indonesia, Jurnal Ekonomi \& Kebijakan Publik (E-ISSN: 2528-4673 PISSN: 2086-6313) Vol. 09 No. 1, 2018, pp 15-27

[24] Sakowitz, Marcin,"How to Evaluate E-Government?, Different Methodologies and Method", Warsaw School of Economics, Departmentof Public Administration, Email: msakow@sgh.waw.pl., 2003

[25] Satapathy, S.S. Mahapatra, S.K. Patel, A. Biswas, P.D. Mishra,"Service satisfaction in E_Electricity service in Odisha (a state of India) by structural equation modeling", Benchmarking: An International Journal, Vol. 21 Issue: 4, 2014, pp.634-650, https://doi.org/10.1108/BIJ-07-2012-0049

[26] Schermernhorn, J. R, “The Innovation Process: a case of new product Development”, 1993 
[27] Narendra.K and Maruteesh K, A Study on Impact of Crop Loan to the Agriculture Development with Special to Refrence Co-Operative Agriculture and Rural Development Bank, International Journal of Advanced Research in Management, 10(1), 2018, pp. 8-33.

[28] Seifert, Jeffrey, W., "A Primer on E-Government: Sector, Stages, Opportunities, and Challenges of Online Governance", Congressional Research Service, The Library of Congress, Updated, January, 28, 2003.

[29] Siddiquee, Alam, N., E-Government and Innovations in Service Delivery. The Malaysian Experience, International Journal of Public Administration, Vol 31, Issue 7, 2008, https://doi.org/10.1080/01900690802153053

[30] Sztop-Rutkowska et al,E-Government Closer to the People, This publication was supported in part by the European Fund through ERASMUS+Adult Education project No 2017-1-PL01-KA204-038688-01 entitled: "E-citizen - effective inclusion through e-governance services", 2019

[31] UN E-Governance Survey, From E Government, to Connected Governance, Department of Economic and Social Affairs Division for Public Administration and Development Management, New York, United Nation, 2008

[32] Faimida M. Sayyad, Proposed Remote Healthcare System for Rural Development, International Journal of Information Technology \& Management Information System (IJITMIS), Volume 4, Issue 1, January - April (2013)

[33] Mohammad Asif Naqshbandi and Dr. Asif Iqbal Fazili, Electronic Governance and Rural Development: A Study on the Impact of ICT on World's Largest Workfare Program (MGNREGA), Journal of Management, 5(5), 2018, pp. 246-254

[34] Van De Walle Steven,Explaining citizen satisfaction with public service, Research Gate, https://researchgate.net/publication321370137, 2016

[35] Dr. Amarja Satish Nargunde, Role of Dairy Industry in Rural Development, International Journal of Advanced Research in Engineering and Technology (IJARET), Volume 4, Issue 2, March - April (2013).

[36] Wahyudi, Andi, "Nilai Tambah dalam Inovasi Pelayanan Publik: Praktek di Unit Pelayanan Terpadu di Kota Pontianak dan Kabupaten Tanah Bumbu", Jurnal Bina Praja, 8 (1) 2016.

[37] Whitton, Howard,"Developing the "Ethical Competence" of Public Officials a Capacity Building Approach", Viesoji Politica Ir Administrativimas, N.r 21, 2007.

[38] Wood, Wallace, Zeffane, Schermerhorn, Hunt \& Osborn, Organization Behavior, An AsiaPacific Perspective, John Willey \& Son, Brisbane, New York, Chichester, Weinheim, Singapore, Toronto, 1998

[39] Dr. Deepasha Gupta, The Impact of Micro Finance on Rural Households and its Role in Rural Development and Poverty Alleviation-An Analysis of North Eastern Villages of U.P, India, International Journal of Management (IJM), Volume 5, Issue 4, April (2014), pp. 145-151.

[40] Zeithaml, Valarie A., Parasuraman. A. And Berry Leonar.L,"Delivering Quality Service Balancing Customer Perception and Expectation”. New York: The Free Press, 1990 